\title{
Use of resistant mutants to characterize the target of mycobacillin in Aspergillus niger membranes
}

\author{
Bhabadeb Chowdhury, ${ }^{1}$ Sanjoy K. Das ${ }^{2}$ and Sushil K. Bose ${ }^{1}$
}

Author for correspondence: Sushil Kumar Bose. Tel: +91475 3680/4681.

1 Department of Biochemistry, University College of Science, 35 Ballygunge Circular Road, Calcutta 700019, India

2 Tumor Biology Laboratory, School of Life Sciences, The University of NebraskaLincoln, Lincoln, NE, USA

\begin{abstract}
The mycobacillin-sensitive Aspergillus niger strain $\mathbf{G}_{3} \mathrm{Br}$ and resistant mutants of it did not show any differences in their total lipid content, although the amounts of phospholipids and sterols, particularly phosphatidylcholine and cholesterol, were lower in resistant cells. Mycobacillin resistance was accompanied by an increase in the phase-transition temperature of plasma membrane preparations. When exposed to mycobacillin, resistant and sensitive cells did not differ qualitatively with respect to most released materials (lysine, proline, $\mathrm{P}_{\mathrm{i}}, \mathrm{Na}^{+}, \mathrm{K}^{+}, \mathrm{Ca}^{2+}$ ); however, the release of ATP was completely inhibited in resistant cells unless they were exposed to concentrations of mycobacillin exceeding their respective MIC value. Resistant cells, under steady-state conditions, displayed greater uptake and release of the same specific materials - except ATP - as sensitive cells did under similar conditions. Thus release and uptake of those materials except ATP are not implicated in the mode of action of mycobacillin. The inhibiting action of mycobacillin (at concentrations higher than the MIC) on sensitive or resistant cells was completely antagonized by ATP (which did not form any complex with mycobacillin) but not by any of the releasable components, either alone or in combination. This observation, coupled with the authors' recent findings on ATP release, indicates that the fungistatic action of mycobacillin is due to excessive ATP release, leading to energy starvation. Interestingly, ATP release during the first $2 \mathrm{~h}$ of incubation with mycobacillin was minimal, but increased to over $96 \%$ during the next $48 \mathrm{~h}$. Release and uptake of ATP via liposomes, prepared with lipid and protein isolated from membranes of the mycobacillinsensitive parent and resistant mutants, showed that mycobacillin action could be inhibited either by resistant protein or by resistant lipid. The mycobacillin target appears to be a lipid-protein site on the membrane of sensitive A. niger $\mathbf{G}_{3}$ Br.
\end{abstract}

Keywords: mycobacillin, ATP transport, Aspergillus niger, membranes, antifungal antibiotic

\section{INTRODUCTION}

Mycobacillin (Majumdar \& Bose, 1958) is a cyclic tridecapeptide wide-spectrum antibiotic (Majumdar \& Bose, 1960; Sengupta et al., 1971), very active against rice blast disease fungus, Piricularia oryzae (Nandi et al., 1975). The antibiotic causes the release of UV-absorbing materials from sensitive cells of the strain Aspergillus niger $\mathrm{G}_{3} \mathrm{Br}$ (Banerjee \& Bose, 1967; Halder \& Bose, 1970). This effect was specifically antagonized not only by exogenous cholesterol and phosphatidylcholine (Halder et al., 1967) but also by lipids isolated from sensitive cells (Halder \& Bose, 1971). This identified cholesterol and phosphatidylcholine as the mycobacillin-binding component of the sensitive cells. The nature of the released materials from the sensitive cells has been subsequently characterized to contain lysine, proline, ATP, $\mathrm{P}_{\mathrm{i}}, \mathrm{Na}^{+}, \mathrm{K}^{+}$and $\mathrm{Ca}^{2+}$ (Das et al., 1986a). However, in the presence of antibiotic, there is marked enhancement of the uptake or release of these specific materials. Saturation kinetics identified the transport processes as carrier-mediated (Das et al., 1986b; Chowdhury \& Bose, 1990). The mycobacillin-induced quenching of fluorescence by 1-anilinonaphthalene 8- 
sulfonate or pyrene by binding to the protoplasts or plasma membrane of sensitive cells indicates that the site of action of the antibiotic might be the membrane (Das et al., 1987).

The membrane target site of mycobacillin remains to be characterized. Development of resistance to a drug can be accompanied by decreased uptake or increased excretion of the drug, chemical modification of the drug or alteration of the target site on the sensitive cell. Therefore we decided to study, in resistant mutants of A. niger, changes of mycobacillin-binding lipids, releasable materials and the carrier proteins involved in the transport process, in order to characterize the mode of action of the antibiotic.

\section{METHODS}

Chemicals and radiochemicals. Mycobacillin was prepared from the culture filtrate of Bacillus subtilis $\mathrm{B} 3$ according to the method of Majumdar \& Bose (1960). Helix pomatia extract was purchased from l'Industrie Biologique Francaise. Phospholipids and sterols were prepared from A. niger $\mathrm{G}_{3} \mathrm{Br}$ by the method of Halder \& Bose (1971). ATP, DTT and EDTA were all obtained from Sigma. $\left[{ }^{3} \mathrm{H}\right] \mathrm{ATP}$ was purchased from Bhabha Atomic Research Centre, Bombay, India. All other chemicals were of reagent grade.

Micro-organisms. A mycobacillin-sensitive strain of Aspergillus niger, $\mathrm{G}_{3} \mathrm{Br}$, and its resistant mutant derivatives were used.

Isolation of mycobacillin-resistant mutants and determination of their stability. A repeated subculture method (Hebeka \& Solotorovsky, 1965) was used for the isolation of mycobacillin-resistant mutants. In practice, a dense spore suspension $\left(2 \times 10^{6}-2.5 \times 10^{6}\right.$ spores $\left.\mathrm{ml}^{-1}\right)$ was incubated with a given concentration of mycobacillin in Czapek broth for $3 \mathrm{~d}$ at $34^{\circ} \mathrm{C}$. Cells were then plated at a suitable dilution in Czapek agar containing mycobacillin to isolate resistant mutants. The resistant mutants at different concentrations were obtained by repeating the process. The colony isolates were transferred to slants containing mycobacillin depending on the resistance level to prevent reversion of the resistant mutants.

The stability of resistant mutants was determined by their reversion frequency. The resistant mutants, which were maintained in mycobacillin-containing media, were subcultured on three successive occasions in mycobacillin-free medium. The colonies at each time were replicated on medium containing different concentrations of mycobacillin to determine their reversion frequency.

Lipid extraction from the sensitive parent strain and resistant mutants. Three-day-old mycelia (5 g dry weight of cells) of wild-type and spontaneous resistant mutants were extracted as described by Halder \& Bose (1971). Crude extracts were then fractionated on silicic acid columns according to Hirsch \& Ahrens (1958) to separate phospholipid and sterol.

Characterization of phospholipid fractions. To resolve individual phospholipids, phospholipid fractions were subjected to thin layer chromatography (TLC) on activated (at $110^{\circ} \mathrm{C}$ for $1 \mathrm{~h}$ ) silica gel $\mathrm{G}(\mathrm{BDH})$ using one-dimensional and, when required, two-dimensional chromatography. Approximately $50 \mu \mathrm{g}$ of sample was used. Phospholipids were identified by cochromatography and visualized by using rhodamine $6 \mathrm{G}$
(Witter et al., 1957) and phosphomolybdic acid in $60 \%$ perchloric acid (Halder \& Bose, 1971). Choline-containing phospholipids were identified with cis-aconite reagent (Vaskovsky \& Suppes, 1971). Phospholipids were quantified according to their phosphorus content (Bartlett, 1959).

Characterization of sterol fractions. Sterol fractions were isolated, applied in a volume of $20 \mu \mathrm{l}$ to activated plates of silica gel $G$, and developed with benzene/ethyl acetate $(5: 1$, $\mathrm{v} / \mathrm{v}$ ). After drying the plates, spots were detected under an ultraviolet lamp or visualized by spraying with phosphoric acid/water $(1: 1, \mathrm{v} / \mathrm{v})$ and heating the plates under an infrared lamp. Sterols were quantified according to the method of Ames (1968).

The cholesterol spot was further confirmed by elution from silica gel with chloroform/methanol $(2: 1, \mathrm{v} / \mathrm{v})$. The eluate was divided into two parts. One part was mixed with an authentic sample of cholesterol, while the other part was used as such. Both samples were applied to silver nitrate impregnated silica gel $\mathrm{G}$ followed by reverse-phase partition chromatography on Kieselgur G impregnated with undecane/ tetradecane $(80: 20, \mathrm{v} / \mathrm{v})$ (Copius-Peerboom \& Becks, 1965; Truswell \& Mitchel 1965) The chromatographs were developed with acetonitrile/water/acetic acid $(75: 2: 23$, by vol.). A cholesterol standard was used for comparison.

Preparation of plasma membranes from the mycobacillinsensitive parent and resistant mutants. Protoplasts isolated from the sensitive parent and resistant mutants were used to prepare plasma membranes, following the method of Bachmann \& Bonner (1959) and further modified by Das et al. (1987). The plasma membrane was further purified by discontinuous sucrose density gradient centrifugation (Markel et al., 1980). Purity of the membrane fraction was confirmed by assays for chitin synthase (Duran et al., 1975) and succinate dehydrogenase (Kasahara \& Anraku, 1974). Freedom from cytoplasmic contaminant proteins was further confirmed by assay of glucose-6-phosphate dehydrogenase (Balinsky \& Bernstein, 1963) and pyruvate kinase (Aust et al., 1975).

Labelling of membranes with pyrene, an excimer-forming probe. The optimum conditions for pyrene incorporation into membranes were first worked out, using various concentrations of pyrene (Sigma) and different times and temperatures of incubation; the conditions selected were $0.05 \mathrm{mg}$ pyrene (mg protein $)^{-1}$ at $37^{\circ} \mathrm{C}$ for $4 \mathrm{~h}$ (data not shown). A thin film of pyrene in chloroform, prepared at the bottom of a round-bottomed flask by evaporating the solvent under a nitrogen atmosphere, was incubated under the optimum conditions in a mixture containing $5 \mathrm{ml}$ membrane suspension

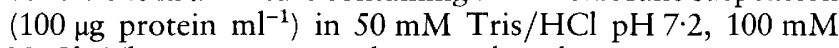
$\mathrm{NaCl}$. The mixture was then incubated on a reciprocating shaker at a speed of 90 strokes $\min ^{-1}$ at $37^{\circ} \mathrm{C}$ for $4 \mathrm{~h}$. Unbound pyrene was removed by centrifugation at $1500 \mathrm{~g}$ for $5 \mathrm{~min}$ followed by dialysis. The supernatant was used for fluorescence measurement with a spectrofluorometer (Turner model 420). Monomer $\left(I_{\mathrm{M}}\right)$ and excimer $\left(I_{\mathrm{E}}\right)$ fluorescence intensities were recorded at $390 \mathrm{~nm}$ and $480 \mathrm{~nm}$ respectively, using $342 \mathrm{~nm}$ as the excitation wavelength.

Since the ratio of the intensities of excimer to monomer radiation $\left(I_{\mathrm{E}} / I_{\mathrm{M}}\right)$ has been shown to be directly related (Galla \& Sackmann, 1974) to (a) the fluidity of the environment, (b) the effective concentration of the probe and (c) temperature, the relationship becomes $I_{\mathrm{F}} / I_{\mathrm{M}}=F$, at a given temperature and concentration, where $F$ is the fluidity parameter, provided there is no change in protein structure or lipid-protein-probe interaction as a consequence of temperature change. Therefore, the $I_{\mathrm{E}} / I_{\mathrm{M}}$ ratio was measured against temperature within 
the range of $10-40^{\circ} \mathrm{C}$. Phase transition was assigned to the region where a change in slope was observed.

Characterization of released materials from different resistant mutants. Release of amino acids, nucleotides, inorganic phosphate and cations was studied as described previously (Das et al., 1986a).

Isolation of membrane protein from membrane vesicles. For reconstitution studies, membrane vesicles were solubilized with $1 \%$ Triton $\mathrm{X}-100$. The solubilized membrane proteins were precipitated by the addition of solid $\left(\mathrm{NH}_{4}\right)_{2} \mathrm{SO}_{4}$ to $80 \%$ saturation by the method of Chowdhury \& Bose (1990), and the amount of membrane protein after solubilization of membrane vesicles was estimated by the Lowry method.

Preparations of liposomes for release and uptake studies. Lipids and sterols (which antagonize the action of mycobacillin and are subsequently termed antimycobacillin; Halder \& Bose, 1973) were used in the preparation of liposomes. These lipids and sterols were isolated by the method of Halder $\&$ Bose (1971) from A. niger $\mathrm{G}_{3} \mathrm{Br}$ and its resistant mutants. Briefly, the mixture of antimycobacillin sterols and lipids (10 $\mathrm{mg}$, as obtained from A. niger) was suspended in $2 \mathrm{ml}$ $40 \mathrm{mM}$ Tris $/ \mathrm{HCl}$ buffer $\mathrm{pH} 7.4$ containing $2 \%$ sodium cholate, $1 \%$ sodium deoxycholate and $1 \mathrm{mM}$ DTT and sonicated in a Tomy probe Sonic Oscillator, model UR-150P, at $20 \mathrm{kHz}$ and $150 \mathrm{~W}$ in an ice bath for $5 \mathrm{~min}$. A $100 \mu \mathrm{g}$ protein sample was added to the above sterol/lipid/detergent mixture $(2 \mathrm{ml})$ and sonicated for $30 \mathrm{~s}$ (Hirata et al., 1976). Then the mixture was dialysed against $50 \mathrm{mM}$ Tris/ $\mathrm{HCl}$ buffer $\mathrm{pH} 7 \cdot 4$ containing $2.5 \mathrm{mM} \mathrm{MgSO}, 0.2 \mathrm{mM}$ EDTA and $0.25 \mathrm{mM}$ DTT for $20 \mathrm{~h}$ at $4{ }^{\circ} \mathrm{C}$. The reconstituted vesicles were centrifuged at $140000 \mathrm{~g}$ for $30 \mathrm{~min}$. The amount of protein incorporated into the reconstituted vesicles was $15 \mu \mathrm{g}$ per $100 \mu \mathrm{g}$ liposome phospholipid.

For uptake studies, reconstituted liposomes at a concentration of $15 \mu \mathrm{g}$ membrane protein per $100 \mu \mathrm{g}$ liposome phospholipid in PBS $(0.05 \mathrm{M}$ phosphate buffer $\mathrm{pH} 6.8$ containing $0.85 \%$ saline and $0.5 \mathrm{mM}$ DTT) containing $5 \mathrm{mM}$ ATP including $2 \mu \mathrm{Ci}\left[{ }^{3} \mathrm{H}\right] \mathrm{ATP}$ (specific radioactivity $2500 \mathrm{Ci} \mathrm{mol}^{-1}, 1 \mathrm{Ci}$ being equivalent to $3.7 \times 10^{10} \mathrm{~Bq}$ ) were incubated for $2 \mathrm{~h}$ at $30^{\circ} \mathrm{C}$. At the end of the incubation period, the liposomes were harvested and washed with ice-cold buffer until the washes were free of radioactivity. Radioactivity was measured for both pellet and supernatant fractions. For release experiments, preloaded vesicles were incubated under similar conditions in the same buffer without ATP and the radioactivity measured as release.

Statistical analysis. Statistical analysis was performed to obtain correlation coefficients using the following formula:

$t=\frac{r \sqrt{ } n-2}{\sqrt{ } 1-r^{2}} \sim t_{n-2}$

where $r$ is the correlation coefficient, $t$ is Student's $t$ statistic and $n$ is the number of samples.

\section{RESULTS}

\section{Characterization of mycobacillin-resistant mutants}

The MIC of mycobacillin for the resistant mutants (MI-MVIII) was 1·25-10 times the MIC for the sensitive parent (Table 1). The stability of the mutants in the absence of mycobacillin was expressed in terms of reversion frequency; in the second and third subculture, in absence of mycobacillin, strains reverted at a frequency of $2-5 \%$ for high-level resistant mutants (data not shown).

The growth yield after $48 \mathrm{~h}$ of some moderately and highly resistant mutants (MIII, MVI and MVIII) decreased with increasing resistance to mycobacillin (Table 1). The total lipid content of these mutants was found to be similar to that of sensitive cells, although their total sterol and phospholipid content showed a decrease with an increase in resistance. The change in the nature of sterols from resistant mutants with increasing resistance was confirmed by the Liebermann-Burchard reaction. The change in colour from purplish blue in the case of the sensitive parent to blue with a green tint and dirty blue in case of the resistant mutants is a characteristic feature of steroids with an unsaturated bond in the ring and not in the side chain (Bladon, 1958). However, the mechanism of colour change is not clear.

\section{Phospholipid and sterol patterns of the mycobacillin- sensitive parent and resistant mutants}

The phospholipids of three representative mycobacillinresistant mutants (MIII, MVI and MVIII), as studied by TLC, showed that the content of phosphatidylcholine decreased slightly with increasing resistance (Table 2). The other major phospholipids at $R_{\mathrm{F}}$ values 0.67 and 0.42 , which were identified as phosphatidylethanolamine and lysophosphatidylethanolamine by co-chromatography, did not show any statistically significant variation (data not shown).

Examination of the sterols of these mycobacillinresistant mutants by TLC showed that cholesterol, a major sterol component of the resistant mutants, decreased significantly with increasing resistance (Table 2), whereas ergosterol and lanosterol, the two other major sterol components, did not show any statistically significant variation (data not shown). Mycobacillin action has been shown to be antagonized not only by cholesterol (Halder et al., 1967) but also by cell lipids of A. niger (Halder \& Bose, 1973), which presumably points to the presence of cholesterol in A. niger cells. However, the presence of cholesterol was demonstrated in these experiments by the method of Copius-Peerboom \& Becks (1965), an observation which to our knowledge has not been reported previously.

\section{Variation of phase transition temperature with development of resistance}

Fig. 1 shows a plot of $I_{\mathrm{E}} / I_{\mathrm{M}}$ versus temperature for the plasma membrane preparations from the sensitive $\mathrm{G}_{3} \mathrm{Br}$ and resistant mutants MI, MIII and MIV. Membranes prepared from the sensitive strain displayed a phase transition temperature of $22^{\circ} \mathrm{C}$ while those from resistant mutants MI, MIII and MIV showed phase transition at temperatures of 26,29 and $30.5^{\circ} \mathrm{C}$ respectively, indicating an increase in phase transition temperature with increase in the level of resistance. 
Table 1. Characterization of the mycobacillin-sensitive parent strain $A$. niger $\mathrm{G}_{3} \mathrm{Br}$ and three representative mycobacillin-resistant mutants

Cultures were grown in Czapek broth at $34^{\circ} \mathrm{C}$. Growth yields were determined after $48 \mathrm{~h}$. After $72 \mathrm{~h}$ growth (stationary phase), the total lipid fraction was prepared by treating $5 \mathrm{~g}$ mycelia (dry wt) with $100 \mathrm{ml}$ chloroform/methanol $(2: 1, \mathrm{v} / \mathrm{v})$. The sterol fraction was eluted with chloroform/methanol $(9: 1, \mathrm{v} / \mathrm{v})$ from a silicic acid column charged with the crude extract. The phospholipid fraction was eluted with chloroform/methanol $(1: 9, \mathrm{v} / \mathrm{v})$ from a silicic acid column charged with the crude extract. See Methods for details. Total lipid extracts of whole cells were used for assay. Preparations from exponential- and stationary-phase cells gave identical results. Results are expressed as means \pm SD of four different sets of experiments.

\begin{tabular}{|c|c|c|c|c|c|}
\hline Strain & $\begin{array}{c}\text { MIC of } \\
\text { mycobacillin } \\
\left(\mathrm{mg} \mathrm{ml}^{-1}\right)\end{array}$ & $\begin{array}{c}\text { Growth yield } \\
\text { [mg dry wt }(100 \mathrm{ml} \\
\left.\text { broth })^{-1}\right]^{*}\end{array}$ & $\begin{array}{c}\text { Total lipid } \\
\text { content } \\
{[\mathrm{mg}(\mathrm{g} \text { cell dry }} \\
\left.\mathrm{wt})^{-1}\right] \dagger\end{array}$ & $\begin{array}{l}\text { Sterol content } \\
{[\mathrm{mg}(\mathrm{g} \text { cell dry }} \\
\left.\mathbf{w t})^{-1}\right]^{*}\end{array}$ & $\begin{array}{l}\text { Phospholipid } \\
\text { content } \\
{[\mathrm{mg}(\mathrm{g} \text { cell dry }} \\
\left.\mathrm{wt})^{-1}\right]^{*}\end{array}$ \\
\hline Parent (sensitive) & $20 \pm 0.55$ & $350 \cdot 5 \pm 2 \cdot 56$ & $105 \cdot 7 \pm 1 \cdot 50$ & $35 \cdot 0 \pm 0 \cdot 85$ & $46 \cdot 1 \pm 0 \cdot 36$ \\
\hline MIII (moderately resistant) & $75 \pm 0.75$ & $219 \cdot 5 \pm 3 \cdot 45$ & $105 \cdot 3 \pm 0 \cdot 55$ & $32 \cdot 5 \pm 0 \cdot 70$ & $43 \cdot 6 \pm 0 \cdot 75$ \\
\hline MVI (highly resistant & $150 \pm 0.75$ & $200 \cdot 2 \pm 4 \cdot 30$ & $105 \cdot 8 \pm 0 \cdot 89$ & $30 \cdot 2 \pm 0 \cdot 42$ & $41 \cdot 4 \pm 1 \cdot 25$ \\
\hline MVIII (highly resistant) & $200 \pm 1 \cdot 25$ & $165 \cdot 3 \pm 2 \cdot 20$ & $105 \cdot 7 \pm 0.85$ & $28 \cdot 2 \pm 0 \cdot 25$ & $40 \cdot 2 \pm 0 \cdot 55$ \\
\hline
\end{tabular}

* Results for mutants significantly different from parent $(P \leqslant 0 \cdot 01)$.

$\dagger$ Results for mutants not significantly different from parent $(P \leqslant 0 \cdot 01)$.

Table 2. Contents of phosphatidylcholine and cholesterol of mycobacillin-sensitive $A$. niger and three representative resistant mutants

Two developing solvent systems were used for one-dimensional TLC: chloroform/methanol $/ 28 \%$ aqueous ammonia $(65: 25: 5$, by vol.) and chloroform/methanol/water $(93: 35: 6$, by vol.). The solvent systems used for two-dimensional TLC were chloroform/methanol $/ 28 \%$ aqueous ammonia $65: 25: 5$, by vol.) and chloroform/acetone/methanol/acetic acid/water $(5: 2: 1: 1: 0 \cdot 5$, by vol. $)$. The results are means \pm SD of four different sets of experiments. Parentheses indicate the percentage decrease of a given phospholipid or sterol content with respect to that in the sensitive strain.

\begin{tabular}{|lcc|}
\hline Strain & $\begin{array}{c}\text { Phosphatidylcholine } \\
{\left[\mathbf{m g}(\mathbf{m g} \text { cell dry wt })^{-1}\right]^{*}}\end{array}$ & $\begin{array}{c}\text { Cholesterol } \\
{[\mathbf{m g} \text { (mg cell dry }} \\
\left.\mathbf{w t})^{-1}\right] \dagger\end{array}$ \\
\hline Sensitive & $20 \cdot 9 \pm 0 \cdot 80(0)$ & $13 \cdot 8 \pm 0 \cdot 35(0)$ \\
MIII & $18 \cdot 6 \pm 1 \cdot 22(11 \cdot 0)$ & $11 \cdot 5 \pm 0 \cdot 75(16 \cdot 6)$ \\
MVI & $16 \cdot 2 \pm 0 \cdot 65(22 \cdot 4)$ & $8 \cdot 9 \pm 0 \cdot 46(35 \cdot 5)$ \\
MVIII & $15 \cdot 2 \pm 0 \cdot 78(27 \cdot 2)$ & $7 \cdot 8 \pm 0 \cdot 80(43 \cdot 4)$ \\
\hline
\end{tabular}

"All the values from the resistant mutants are significantly different from the parent $(P \leqslant 0 \cdot 01)$.

† All the values from the resistant mutants are significantly different from the parent $(P \leqslant 0 \cdot 01)$.

\section{Variation in the nature and amount of materials released by different resistant mutants in absence of mycobacillin}

The representative resistant mutants studied (MII, MIII, MIV, MVII and MVIII) released lysine, proline, $\mathrm{P}_{\mathrm{i}}, \mathrm{Na}^{+}$, $\mathrm{K}^{+}$and $\mathrm{Ca}^{2+}$, but not ATP, while sensitive cells released all these constituents (Table 3). Aspartic acid, which

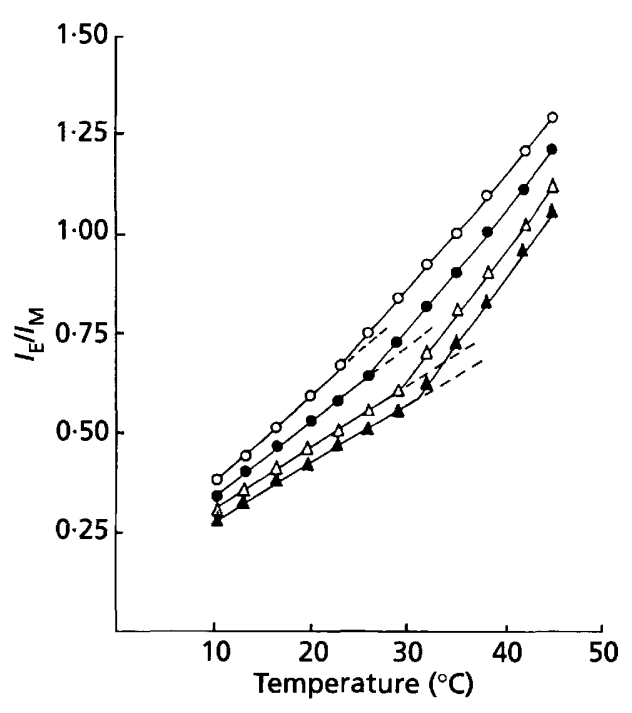

Fig. 1. Plot of $I_{E} / I_{M}$ against temperature for the plasma membrane preparations obtained from different mycobacillinresistant mutants.. $\mathrm{Ml} ; \triangle, \mathrm{MII} ; \mathbf{\Delta}, \mathrm{MIV}$; $\mathrm{O}$, sensitive parent.

was not released by sensitive cells, was released by
mycobacillin-resistant cells. Resistant mutants generally
released higher amounts of cell materials than parental
cells, except in the case of proline. The release of all
materials studied (except ATP) by different resistant
mutants increased significantly with the level of re-
sistance. However, when the resistance level reached
$75 \mu \mathrm{g} \mathrm{m} \mathrm{m}^{-1}$ (for the mutant MIII), the release by resistant
mutants also showed statistically significant decreases.
Thus, release by high-level and low-level resistant
mutants did not show any statistically significant vari-
ation. Interestingly, ATP was not released even by
strains with a high level of resistance.


Table 3. Release of various materials by mycobacillin-sensitive $A$. niger and five resistant mutants in the absence of mycobacillin

Cells were first depleted and then preloaded with different substrates. Cultures were grown in Czapek broth for $48 \mathrm{~h}$ at $34{ }^{\circ} \mathrm{C}$ under stationary conditions. Preloaded cells were suspended in $50 \mathrm{mM}$ Tris/maleate buffer $\mathrm{pH} 7 \cdot 0$ to $10 \mathrm{mg}$ wet weight cells $\mathrm{ml}^{-1}$ and incubated with gentle shaking at $37^{\circ} \mathrm{C}$ for $2 \mathrm{~h}$ (Das et al., 1968a). Results are expressed as means \pm SD of four different sets of experiments in each case. See text for details of significance. $P \leqslant 0.05$ for MI to MVIII with respect to the sensitive strain; $P \leqslant 0.01$ for MI to MIII with respect to the sensitive strain. - , No release.

\begin{tabular}{|c|c|c|c|c|c|c|c|c|}
\hline \multirow[t]{2}{*}{ Strain } & \multicolumn{8}{|c|}{ Amount of different materials released $\left[\mathrm{nmol}(\mathrm{mg} \text { cell dry wt })^{-1}\right]$} \\
\hline & Lysine & Proline & ATP & $\mathbf{P}_{\mathrm{i}}$ & $\mathrm{Na}^{+}$ & $\mathbf{K}^{+}$ & $\mathrm{Ca}^{2+}$ & $\begin{array}{l}\text { Aspartic } \\
\text { acid }\end{array}$ \\
\hline Sensitive & $23 \cdot 9 \pm 0.75$ & $373 \cdot 8 \pm 3 \cdot 25$ & $2 \cdot 7 \pm 0 \cdot 2$ & $12 \cdot 7 \pm 0 \cdot 25$ & $43 \cdot 2 \pm 0 \cdot 45$ & $86 \cdot 6 \pm 2 \cdot 10$ & $2 \cdot 2 \pm 0 \cdot 02$ & - \\
\hline MII & $42 \cdot 2 \pm 0 \cdot 92$ & $384 \cdot 2 \pm 0 \cdot 75$ & - & $22 \cdot 2 \pm 0 \cdot 25$ & $66 \cdot 2 \pm 1 \cdot 20$ & $109 \cdot 2 \pm 1 \cdot 75$ & $7 \cdot 2 \pm 0 \cdot 01$ & $61 \cdot 5 \pm 0 \cdot 90$ \\
\hline MIII & $45 \cdot 0 \pm 1 \cdot 20$ & $386 \cdot 4 \pm 2 \cdot 80$ & - & $24 \cdot 8 \pm 0 \cdot 20$ & $74 \cdot 3 \pm 1 \cdot 50$ & $115 \cdot 0 \pm 1 \cdot 20$ & $7.9 \pm 0.05$ & $62 \cdot 0 \pm 1 \cdot 20$ \\
\hline MIV & $43 \cdot 1 \pm 0 \cdot 50$ & $383 \cdot 9 \pm 4 \cdot 45$ & - & $23 \cdot 7 \pm 0 \cdot 45$ & $69 \cdot 5 \pm 0.75$ & $111 \cdot 2 \pm 0.95$ & $6 \cdot 4 \pm 0.03$ & $61.5 \pm 0.55$ \\
\hline MVII & $29 \cdot 2 \pm 0.55$ & $378 \cdot 0 \pm 0 \cdot 90$ & - & $17 \cdot 2 \pm 0 \cdot 15$ & $48 \cdot 7 \pm 2 \cdot 2$ & $92 \cdot 4 \pm 1 \cdot 10$ & $5 \cdot 2 \pm 0 \cdot 05$ & $55.0 \pm 0.66$ \\
\hline MVIII & $26 \cdot 2 \pm 0 \cdot 42$ & $374.5 \pm 1 \cdot 85$ & - & $15 \cdot 0 \pm 0 \cdot 35$ & $41 \cdot 8 \pm 0 \cdot 90$ & $88 \cdot 2 \pm 0.75$ & $4.8 \pm 0.08$ & $53 \cdot 1 \pm 1 \cdot 30$ \\
\hline
\end{tabular}

Table 4. Release (a) and uptake (b) of various materials by the mycobacillin-sensitive parent and the resistant mutant MIII in the absence and in the presence of various concentrations of mycobacillin

Values are means \pm SD of four sets of experiments in each case. - , No release or no uptake.

\begin{tabular}{|c|c|c|c|c|c|c|c|c|c|}
\hline Strain & $\begin{array}{c}\text { Concn } \\
\text { of mycobacillin } \\
\left(\mu \mathrm{g} \mathrm{ml}^{-1}\right)\end{array}$ & Lysine & Proline & ATP & $\mathbf{P}_{\mathrm{i}}$ & $\mathrm{Na}^{+}$ & $\mathbf{K}^{+}$ & $\mathrm{Ca}^{2+}$ & $\begin{array}{l}\text { Aspartic } \\
\text { acid }\end{array}$ \\
\hline & & \multicolumn{8}{|c|}{ (a) Amount of cell constituent released [ $\mathrm{nmol}$ (mg cell $\mathrm{dry}$ wt) ${ }^{-1}$ ] } \\
\hline \multirow[t]{3}{*}{ Sensitive } & 0 & $23 \cdot 8 \pm 0 \cdot 46$ & $373 \cdot 2 \pm 4 \cdot 47$ & $2 \cdot 7 \pm 0 \cdot 15$ & $12 \cdot 8 \pm 0.42$ & $43.5 \pm 0.85$ & $86 \cdot 6 \pm 1 \cdot 42$ & $2 \cdot 2 \pm 0.02$ & - \\
\hline & 50 & $54 \cdot 2 \pm 0.87$ & $703 \cdot 0 \pm 2 \cdot 58$ & $8.9 \pm 0.20$ & $17 \cdot 5 \pm 0 \cdot 39$ & $124 \cdot 5 \pm 1 \cdot 35$ & $109 \cdot 0 \pm 1 \cdot 35$ & $4.8 \pm 0.09$ & - \\
\hline & 150 & $54.6 \pm 0.58$ & $704 \cdot 8 \pm 3 \cdot 00$ & $35 \cdot 6 \pm 0 \cdot 43$ & $17 \cdot 9 \pm 0.45$ & $142 \pm 2 \cdot 02$ & $112 \pm 1 \cdot 20$ & $5 \cdot 2 \pm 0 \cdot 25$ & - \\
\hline \multirow[t]{4}{*}{ MIII } & 0 & $45 \cdot 5 \pm 0.42$ & $386 \cdot 5 \pm 2 \cdot 14$ & - & $24 \cdot 8 \pm 0 \cdot 22$ & $74 \cdot 3 \pm 0.74$ & $115 \pm 0.42$ & $6 \cdot 2 \pm 0.22$ & $62 \pm 0.45$ \\
\hline & 50 & $64 \cdot 4 \pm 0.43$ & $725 \pm 2.99$ & - & $28 \cdot 0 \pm 0.52$ & $160 \pm 1 \cdot 05$ & $125 \pm 2 \cdot 00$ & $7 \cdot 0 \pm 0.35$ & $84 \pm 0.68$ \\
\hline & 150 & $62.4 \pm 0.25$ & $729 \cdot 2 \pm 4 \cdot 88$ & $22 \cdot 2 \pm 0.45$ & $30.5 \pm 0.53$ & $178 \pm 1 \cdot 25$ & $123 \pm 1 \cdot 75$ & $7 \cdot 2 \pm 0 \cdot 42$ & $85 \pm 1.35$ \\
\hline & & \multicolumn{8}{|c|}{ (b) Amount of cell constituent taken up [nmol (mg cell dry wt $)^{-1}$ ] } \\
\hline \multirow[t]{3}{*}{ Sensitive } & 0 & $38 \cdot 5 \pm 0 \cdot 38$ & $585 \pm 1.02$ & $9.5 \pm 0.20$ & $18 \pm 0 \cdot 50$ & $65 \pm 1 \cdot 25$ & $102 \pm 2 \cdot 22$ & $4 \cdot 5 \pm 0 \cdot 15$ & - \\
\hline & 50 & $62 \pm 0.23$ & $800 \pm 0.74$ & $20 \pm 0.35$ & $25.5 \pm 1.01$ & $145 \pm 0.85$ & $131 \pm 2.55$ & $9 \cdot 0 \pm 0 \cdot 17$ & - \\
\hline & 150 & $68 \pm 0.66$ & $938 \pm 2 \cdot 75$ & $64 \pm 1 \cdot 10$ & $25 \cdot 8 \pm 0.65$ & $180 \pm 2 \cdot 28$ & $165 \pm 0.79$ & $9 \cdot 4 \pm 0.05$ & - \\
\hline \multirow[t]{3}{*}{ MIII } & 0 & $76 \pm 0.65$ & $722 \pm 3 \cdot 20$ & - & $45.5 \pm 1.55$ & $155 \pm 1 \cdot 25$ & $155 \pm 1.55$ & $13 \pm 0 \cdot 20$ & $95 \pm 0.45$ \\
\hline & 50 & $94 \cdot 2 \pm 1 \cdot 10$ & $1120 \pm 8 \cdot 25$ & - & $49 \pm 0.75$ & $245 \pm 2 \cdot 56$ & $189 \pm 3.50$ & $14 \cdot 6 \pm 0.35$ & $122 \pm 0.92$ \\
\hline & 150 & $99.5 \pm 0.22$ & $1075 \pm 2 \cdot 60$ & $38 \pm 0.50$ & $51 \cdot 2 \pm 1 \cdot 20$ & $268 \pm 4 \cdot 25$ & $195 \pm 3.00$ & $15 \cdot 1 \pm 0 \cdot 15$ & $128 \pm 0.45$ \\
\hline
\end{tabular}

\section{Release and uptake as a function of mycobacillin concentration by different mycobacillin-resistant mutants}

Table 4(a) shows the effect of various concentrations of mycobacillin (data shown for some selective concentrations only) on the release of cations, amino acids, $\mathrm{P}_{i}$ and ATP from resistant mutant MIII and the sensitive parent. The pattern (relative proportions of the materials) of release of lysine, proline, $\mathrm{P}_{1}, \mathrm{Na}^{+}, \mathrm{K}^{+}$and $\mathrm{Ca}^{2+}$ by the parent and the resistant mutant was almost identical; however, the amounts released by the mutant were generally higher than those for the sensitive parent. The resistant mutants MI and MIV behaved similarly to MIII (data not shown).

The uptake experiments were done with all releasable materials (Table 4b). Under steady-state conditions, the resistant mutant MIII showed a higher uptake of releasable materials than the parent. This may explain the higher release of these materials by the mutant. The other two resistant mutants, $\mathrm{MI}$ and MIV, again behaved similarly to MIII (data not shown).

The release of ATP by sensitive parent cells increased with the concentration of myobacillin. The release of ATP (Table 4a) by the resistant mutant MIII also increased with increasing concentrations of mycobacillin provided that the concentration of mycobacillin was higher than its MIC for the resistant mutant $\left(75 \mu \mathrm{g} \mathrm{ml}^{-1}\right)$. The pattern of release of the sensitive parent and resistant mutant MIII in response to increasing mycobacillin concentration was almost identical, more ATP was released by the sensitive parent than 
Table 5. Effect of mycobacillin on release and uptake of ATP by liposomes prepared with lipid and protein isolated from the membranes of the mycobacillin-sensitive parent and resistant mutants MII and MVI

Values, expressed as nmol per $100 \mu \mathrm{g}$ liposome lecithin, are means $\pm \mathrm{SD}$ of four sets of experiments in each case. -, No uptake or no release.

\begin{tabular}{|c|c|c|c|c|c|c|c|c|c|}
\hline \multirow[t]{2}{*}{$\begin{array}{l}\text { Liposomes } \\
\text { prepared with* }\end{array}$} & \multirow{2}{*}{$\begin{array}{c}\text { Mycobacillin } \\
\text { concn } \\
\left(\mu \mathrm{g} \mathrm{ml}^{-1}\right) \ldots\end{array}$} & \multicolumn{4}{|c|}{$\begin{array}{l}\text { Release of entrapped }\left[{ }^{3} \mathrm{H}\right] \mathrm{ATP} \\
\text { from liposomes }\end{array}$} & \multicolumn{4}{|c|}{$\begin{array}{l}\text { Uptake of }\left[{ }^{3} \mathrm{H}\right] \mathrm{ATP} \\
\text { by lipsomes }\end{array}$} \\
\hline & & 20 & $\mathbf{5 0}$ & 100 & 150 & 20 & 50 & 100 & 150 \\
\hline $\mathrm{SL}+\mathrm{SP}$ & & $2 \cdot 5 \pm 0.02$ & $9 \cdot 2 \pm 0 \cdot 22$ & $16 \pm 0 \cdot 35$ & $19 \pm 0.48$ & $2 \pm 0.03$ & $10 \pm 0 \cdot 25$ & $18.5 \pm 0.35$ & $20 \pm 0 \cdot 40$ \\
\hline $\mathrm{SL}+\mathrm{RP}(\mathrm{MII})$ & & - & - & $3 \cdot 2 \pm 0.04$ & $4 \pm 0.08$ & - & - & $3 \pm 0.03$ & $4 \cdot 2 \pm 08$ \\
\hline $\mathrm{SL}+\mathrm{RP}(\mathrm{MVI})$ & & - & - & - & $3.5 \pm 0.08$ & - & - & - & $4 \pm 0 \cdot 04$ \\
\hline
\end{tabular}

*SL, lipid from sensitive strain; SP, protein from sensitive strain; RP, protein from resistant strain (mutant number in parentheses).

by the mutant. The pattern of release with the other two mutants was similar to that for MIII (data not shown).

\section{Antagonization of the growth-inhibiting action of mycobacillin}

When mycobacillin-induced releasable constituents were added to cultures of the sensitive parent, alone or in different combinations with mycobacillin, growth inhibition occurred in all cases except those where ATP was added simultaneously with the antibiotic (data not shown). Similar experiments with the resistant mutants, with the antibiotic added at a concentration higher than its MIC for the respective strain, showed that ATP could also antagonize the action of mycobacillin in the case of the mutants (data not shown). These results suggest that growth inhibition by mycobacillin is due to the release of ATP (data not shown).

Mycobacillin, when incubated with $\left[{ }^{3} \mathrm{H}\right] \mathrm{ATP}$ at $\mathrm{pH} 7 \cdot 3$, $37^{\circ} \mathrm{C}$ for $2 \mathrm{~h}$ and then separated chromatographically at $\mathrm{pH} 7 \cdot 3$ or by precipitation at $\mathrm{pH} 3 \cdot 0$, did not contain any radioactive ATP. This indicated that mycobacillin was not complexed with ATP.

\section{Effect of mycobacillin concentrations on release of ATP}

Release of ATP in the absence and in the presence of various concentrations of mycobacillin from the sensitive parent strain of $A$. niger and its resistant mutant derivatives was studied (data not shown). The parent strain showed, within $48 \mathrm{~h}$, a $9 \%$ release of ATP in the absence of mycobacillin and $96 \%$ release in the presence of the antibiotic at its MIC $\left(20 \mu \mathrm{g} \mathrm{m}^{-1}\right)$. The resistant mutant MII, for which the mycobacillin MIC was $50 \mu \mathrm{g} \mathrm{ml}^{-1}$, showed low release $(2 \cdot 5 \%)$ over a period of $48 \mathrm{~h}$ even at $50 \mu \mathrm{g} \mathrm{ml}^{-1}$ of the antibiotic. The release was, however, increased to $58 \%$ when the resistant mutant MII was exposed to a concentration of $100 \mu \mathrm{g} \mathrm{ml}^{-1}$, which far exceeded the MIC. Resistant mutant MIV behaved similarly.

\section{Characterization of the action of mycobacillin by use of liposomes containing membrane lipids and membrane protein}

Mycobacillin caused an increase in the release or uptake of ATP from liposomes prepared with protein and lipid isolated from the membranes of sensitive cells (Table 5). However, no such release or uptake of ATP occurred from liposomes prepared with lipids and proteins isolated from the membrane of resistant mutants at any concentration of mycobacillin even when its concentration exceeded the MIC values for the resistant mutants in question (data not shown). This is in contrast to the data from eperiments on the release or uptake of ATP by intact mycobacillin-resistant cells (Table 4a, b). Additionally, when liposomes were prepared with membrane proteins from the sensitive parent and lipids from the resistant mutant, mycobacillin at all concentrations tested did not cause any release or uptake of ATP (data not shown). Liposomes prepared with membrane proteins from the resistant mutants and membrane lipid from the sensitive parent also did not show release or uptake of ATP. However, feeble release or uptake of ATP was observed when mycobacillin concentrations were higher than the MIC for the resistant mutants (Table 5). Thus mycobacillin activity was blocked by either protein or lipid from resistant cells. However, these experiments did not indicate the functional interdependence between these two components, lipids and proteins, of the resistant mutants except for the fact that both the components probably play a major role in the development of resistance.

\section{DISCUSSION}

We employed mycobacillin-resistant mutants of $A$. niger $\mathrm{G}_{3} \mathrm{Br}$ to study the mode of action of mycobacillin. These studies showed that the resistant mutants were very different from the sensitive parent in lipid composition, membrane fluidity, and the ATP transport system.

The resistant mutants were altered in their lipid composition, and their content of cholesterol and phos- 
phatidylcholine, but not that of ergosterol or lysophosphatidylethanolamine, was considerably decreased. Therefore, cholesterol and phosphatidylcholine may be the mycobacillin target molecules. This observation agrees with earlier findings that the action of mycobacillin was antagonized by exogenously added cholesterol and phosphatidylcholine (Halder et al., 1967) and by the cell lipids of A. niger (Halder \& Bose, 1971, 1973). That the membrane may be the reactive site for mycobacillin action was noted earlier (Das et al., 1987) and consequently the resistant mutants may be much altered in their membranes. This was further corroborated by the increase in phase transition temperature with the increase in mycobacillin resistance observed in the present study.

Since alteration in the composition of membrane lipid affects its fluidity and hence its permeability, we analysed the uptake and release properties of the resistant mutants. Interestingly, these studies on the nature and amount of materials released by the parent and resistant mutants in the absence and in the presence of different concentrations of mycobacillin showed that mycobacillin-resistant mutants resembled, qualitatively, the sensitive parent with respect to most of the releasable constituents studied - lysine, proline, $\mathrm{P}_{\mathrm{i}}, \mathrm{Na}^{+}, \mathrm{K}^{+}$and $\mathrm{Ca}^{2+}$. The only exceptions were ATP, released by the parent but not the mutants, and aspartic acid, released by the mutants but not the parent.

There were some quantitative differences between the mutants and the parent in the release of constituents and therefore uptake studies were pursued. Uptake studies under steady-state conditions showed that with resistant cells, higher uptake was accompanied by higher release and lower uptake by lower release. In other words, release is quantitatively related to uptake under steadystate conditions. Therefore the quantitative difference in released products may not be an answer to the mode of action of mycobacillin. ATP, however, behaves differently.

ATP release was completely blocked in the mycobacillin-resistant mutants, except when the mutant cells were exposed to mycobacillin at concentrations higher than the MIC for a given resistant mutant. This suggests that ATP release is involved in the antifungal action. However, the lower release of ATP in resistant mutants compared to the sensitive parent might be due to the decreased level of ATP uptake under steady-state conditions. Furthermore, ATP but none of the releasable materials either alone or in combination when added simultaneously with mycobacillin antagonized its growth-inhibiting action (data not shown). This was also seen with cholesterol or lipid (Halder \& Bose, 1973). However, whereas cholesterol and phosphatidylethanolamine formed a complex with the antibiotic, ATP did not, suggesting a different mode of action.

The release of ATP in response to mycobacillin at MIC level was marginal. However, in earlier studies the experiment was continued for only $2 \mathrm{~h}$, when ATP reached its peak value, and there was no information on whether ATP release declined. Experiments were therefore designed to determine the amount of ATP release if monitored for longer periods. These studies showed ATP release by sensitive cells to the extent of $96 \%$ over $48 \mathrm{~h}$ in the presence of mycobacillin at MIC level. Resistant mutants showed similar behaviour when exposed to higher concentrations of mycobacillin over $48 \mathrm{~h}$. Thus, the release of ATP and consequent energy starvation, which is feeble in absence of mycobacillin, but greatly enhanced by its presence, might be involved in the mechanism of mycobacillin action. However, it has not been possible to correlate the progressive decline in viability with the degree of ATP release from the test cells of $A$. niger $\mathrm{G}_{3} \mathrm{Br}$ as mycobacillin is fungistatic and not fungicidal (Banerjee \& Bose, 1963).

The resistant mutants were altered in their lipid composition, membrane fluidity and also in ATP transport activities. Either cell lipid or ATP transport protein, or both, could be implicated in the action of mycobacillin on the sensitive cells. Experiments with liposomes prepared with different combinations of lipids and proteins obtained from mycobacillin-sensitive parent or resistant mutants revealed that the action of mycobacillin on the release or uptake of ATP was inhibited either by lipid or by protein isolated from resistant mutants.

Since either the protein or the lipid could be the reactive component, the mycobacillin target might therefore be a lipoprotein site on the membrane of mycobacillinsensitive A. niger $\mathrm{G}_{3} \mathrm{Br}$. This observation is supported by our recent finding that the sensitive $A$. niger membrane contains an ATP transport protein which specifically transports only intact ATP molecules across the cytoplasmic membrane. Mycobacillin enhances this transport activity. The enhancing action of the drug on release or uptake, which is feeble in its absence, showed Michaelis-Menten kinetics (Chowdhury et al., 1997). This indicates the non-competitive nature of the action of mycobacillin, which therefore binds the transport protein at a site other than the mycobacillin-binding site. As the enhancing action of mycobacillin is antagonized by cholesterol or lecithin, it is possible that the ATP transport protein functions in conjunction with mycobacillin-reactive lipid(s) whose association (physical or physico-chemical) causes less release in the native form in the absence of mycobacillin than it does when altered by mycobacillin. Thus the mycobacillin target is tentatively identified as an ATP transport protein and an as yet unidentifed mycobacillin-reactive lipid.

\section{ACKNOWLEDGEMENTS}

We thank the Council of Scientific and Industrial Research, New Delhi, for financial assistance.

\section{REFERENCES}

Ames, G. I. (1968). Lipid of Salmonella typhimurium and Escherichia coli: structure and metabolism. J Bacteriol 95, 833-843. 
Aust, A., Shyun-Long, Y. \& Suelter, C. H. (1975). Pyruvate kinase from yeast. Methods Enzymol 42, 176-182.

Bachmann, B. J. \& Bonner, D. M (1959). Protoplasts from Neurospora crassa. J Bacteriol 78, 550-556.

Balinsky, D. \& Bernstein, R. E. (1963). The purification and properties of glucose-6-phosphate dehydrogenase. Biochim Biophys Acta 67, 313-315.

Banerjee, N. \& Bose, S. K. (1963). Mode of action of mycobacillin, a new antifungal antibiotic. J Bacteriol 86, 387-391.

Banerjee, N. \& Bose, S.K. (1967). Action of mycobacillin on cell wall permeability of a sensitive strain of Candida albicans. In International Symposium on Mechanism of Action of Fungicides and Antibiotics, pp. 107-113. Berlin: Biologischen Gesellschaft in der DDR, Akademie-Verlag.

Bartlett, G. R. (1959). Phosphorus assay in column chromotography. J Biol Chem 234, 466-468.

Bladon, P. (1958). Chemistry. IX. Colour reactions of steroids. In Cholesterol: Chemistry, Biochemistry and Pathology, pp. 84-88. Edited by R. P. Cook. New York: Academic Press.

Chowdhury, B. \& Bose, S. K. (1990). Identification and isolation of ATP transport protein in mycobacillin sensitive Aspergillus niger. J Biosci 15, 163-168

Chowdhury, B., Das, S. K. \& Bose, S. K. (1997). Isolation and properties of ATP transporter from a strain of Aspergillus niger. Eur J Biochem 247, 673-680.

Copius-Peerboom, J. W. \& Becks, H. W. (1965). The analysis of mixtures of animal and vegetable fats. V. Separation of sterol acetates by thin layer chromatography in reversed phase systems and on silica gel G-silver nitrate layer. J Chromatogr 17, 99-106.

Das, S. K., Majumdar, S., Basu, S., Mukherjee, S. \& Bose, S. K. (1986a). Selective action of mycobacillin on the cellular permeability of Aspergillus niger. J Antibiot 39, 581-588.

Das, S. K., Basu, S., Majumdar, S. \& Bose, S. K. (1986b). Selective action of mycobacillin on the uptake of releasable cell materials by Aspergillus niger. Biochem J 239, 317-323.

Das, S. K., Mukherjee, S., Majumdar, S., Basu, S. \& Bose, S. K. (1987). Physicochemical interaction of mycobacillin with Aspergillus niger protoplast membrane, the site of its action. J Antibiot 40, 1036-1043.

Duran, A., Bowers, B. \& Cabib, E. (1975). Chitin synthetase zymogen is attached to the yeast plasma membrane. Proc Natl Acad Sci USA 72, 3952-3955.

Galla, H. J. \& Sackmann, E. (1974). Lateral diffusion in the hydrophobic region of membranes: use of pyrene excimers as optical probes. Biochim Biophys Acta 339, 103-115.
Halder, A. \& Bose, S. K. (1970). Action of mycobacillin on filamentous fungi. Acta Microbiol Pol Ser B 2, 25-30.

Halder, A. \& Bose, S. K. (1971). Reversal of mycobacillin inhibition reactions of sterol and phospholipids. J Antibiot 24, 779-784.

Halder, A. \& Bose, S. K. (1973). Mechanism of sterol and lipid antagonism of a polypeptide antibiotic, mycobacillin. J Antibiot 26, 358-361.

Halder, A., Bhattacharya, P., Banerjee, N. D. \& Bose, S. K. (1967). Antagonistic action of cholesterol on mycobacillin. J Bacteriol 93 , 2026-2028.

Hebeka, E. K. \& Solotorovsky, M. (1965). Development of resistance of polyene antibiotics in Candida albicans.J Bacteriol 89, 1533-1539.

Hirata, H., Sone, N., Yoshida, M. \& Kagawa, Y. (1976). Solubilization and partial purification of alanine carrier from membranes of a thermophilic bacterium and its reconstitution into functional vesicles. Biochem Biophys Res Commun 69, 665-671.

Hirsch, J. \& Ahrens, E. (1958). Separation of complex lipid mixtures by the use of silicic acid column chromatography. J Biol Chem 233, 311-320.

Kasahara, M. \& Anraku, Y. (1974). Succinate dehydrogenase of Escherichia coli membrane vesicles. J Biochem 76, 959-966.

Majumdar, S. K. \& Bose, S. K. (1958). Mycobacillin, a new antifungal antibiotic produced by Bacillus subtilis. Nature 181, 134-135.

Majumdar, S. K. \& Bose, S. K. (1960). Isolation and homogeneity of mycobacillin. Arch Biochem Biophys 90, 154-158.

Markel, G. I., Naider, F. \& Becker, J. M. (1980). Amino acid uptake by Saccharomyces cerevisiae plasma membrane vesicles. Biochim Biophys Acta 595, 109-120.

Nandi, J., De, B. K. \& Bose, S. K. (1975). Antifungal spectrum and phytotoxicity. J Antibiot 28, 988-992.

Sengupta, S., Banerjee, A. B. \& Bose, S. K. (1971). Glutamyl and Dor L-peptide linkages in mycobacillin, a cyclic peptide antibiotic. Biochem J 121, 839-846.

Truswell, A. W. \& Mitchel, W. D. (1965). Separation of cholesterol from its companions, cholestanol and 7-cholestanol, by thin layer chromatography. J Lipid Res 6, 438-442.

Vaskovsky, V. E. \& Suppes, Z. S. (1971). Detection of choline containing lipids on thin layer chromatograms. J Chromatogr 63, 455-456.

Witter, R. F., Marinetti, G. V., Morrison, A. \& Heicklin, L. (1957). Paper chromatography of phospholipids with solvent mixtures of ketones and acetic acid. Arch Biochem Biophys 68, 15-20.

Received 28 May 1997; revised 6 October 1997; accepted 10 October 1997. 